Contents lists available at Џournal IICET

JPPI (Jurnal Penelitian Pendidikan Indonesia)

ISSN: 2502-8103 (Print) ISSN: 2477-8524 (Electronic)

\title{
Local content: a new instructional in EFL writing autobiography (participatory action research on tourism class)
}

\author{
Hamzani Wathoni ${ }^{*}$, Hasan Basri \\ Universitas Hamzanwadi, Indonesia
}

\begin{tabular}{l} 
Article Info \\
\hline Article history: \\
Received Jun $08^{\text {th }}, 2021$ \\
Revised Jul $11^{\text {th }}, 2021$ \\
Accepted Aug $22^{\text {th }}, 2021$ \\
\hline
\end{tabular}

\section{Keyword:}

Content-based learning

Tourism class

EFL

Autobiography

\begin{abstract}
Genres-based text in the content area of writing has long been practiced, yet the theme's content sometimes does not match learners' needs - this research aimed at discovering the effectiveness of local content-based learning media in teaching English for the tourism class. The local content selected was local public figures to write an autobiography. This research applied for participatory action research taking place in one-class English for tourism. A total of fifteen course-takers for the three-month course were recruited, documenting how the idea of local content we proposed was used to teach tourism students' writing with the test as the instrument. The teaching content is restricted to two formulated indicators; comprehending text structure and language features, including using to be and pronoun. Findings indicate that local content effectively improved course takers' comprehension of the descriptive text structure and increased vocabulary. The majority of coursetakers reflected a significant improvement to meet classical passing grades in the last teaching evaluation. The diagnostic test previously was under stipulated standardized-score. The course-takers successfully wrote narration using local public figures to apply" to be" in good sentences. Moreover, overlapping use of masculine and feminine was distinguished correctly and positioned in well-constructed narrative text.
\end{abstract}

(C) 2021 The Authors. Published by IICET.

This is an open access article under the CC BY-NC-SA license

(https://creativecommons.org/licenses/by-nc-sa/4.0

\section{Corresponding Author:}

Hamzani Wathoni,

Universitas Hamzanwadi

Email: wathoni@hamzanwadi.ac.id

\section{Introduction}

Teaching communicative English for foreign learner (EFL) classrooms constitutes a full intention among English teachers in formal and non-formal schools. Communicative language teaching is imperative as it covers an extensive language input active and dynamic learning (Ho 2020). Selective methods and planned learning activities are considered essential in effective teaching (Rus and Rus 2020). Learning is then interpreted as a form of a teacher's action in accomodating needs (Elizabeth and Plessis 2018), shaping the desired behavior, and providing an environment of learning enjoyment (Inharjanto and Lisnani 2021), allowing learners to learn. This definition means that a creative method to stimulating opportunities (Rankin and Brown 2015) supports facilities to support students' interest cognitively (Vieluf and Kerstin 2019); critically about an object to better subject matter understanding is highly required.

Productive teachers are teachers with potent creativity. Their roles and beliefs guide classroom practices ( $\mathrm{Li}$ 2019; Wirawan 2020) and reconstruct learning activities. In EFL classroom teaching, the teacher emphasizing one distinctive approach such as self-directed learning is critically helpful. Such an approach would benefit 
students' language input because of the complexity of the task and time limit in a formal setting (Akbari 2015). Furthermore, this can succeed in selecting teaching materials to build creativity to skill development and adaptable classroom (Wang and Kokotsaki 2018). The setting of class size is becoming more considerable as the teachers in smaller classrooms do more, speak and establish tight relationships, and demonstrate individual interest. As classrooms are communicative, activities are becoming personalized and adapted (Garcia-Ponce and Tagg 2020), in the sense that textbook sometimes does not include activities in real life. The next step is to create a creative behavior to bind students' behaviors completely and innovation (Huang, Chi-Kin Lee, and Yang 2019) and reflect on their experiences.

With the application of media, the teachers' obligation toward teaching and learning should not be burdensome. The media engages the learning process motivating (Sholihin et al. 2020) in addition to educational innovation for a whole (Manca and Ranieri 2016a). In its capacity, media is widely acceptable for today's millennials (Li, Sun, and Jee 2019) and z generation (Montiel et al. 2020) in terms of digital natives. It is commonly understood that the role of media facilitates students a lot, even for children level (Salinas et al. 2016). As media support well-constructed classroom activities, it provides collaborative rooms, shares common thinking to minimize boredom. The media in the context of EFL learning, look, and content are essential to design. Analysis of needs is also helpful and contextualizes topics selected. The organization of factors of contextual understanding must be on learning principles supporting students' interest in collaborating to build ideas and experiences in education. Furthermore, various media support such as game plays a significant role in stimulating students' involvement (Tsai, Chang, and Lo 2017). Social media enables young learners to share ideas (Al-Jarrah et al. 2019), create and discuss content dynamically (Manca and Ranieri 2016b), becoming an effective platform of teaching (Peralta and Caporusso 2020).

Applying innovative teaching media as instructional in some schools in Lombok Timur has received a small concern among teachers. They rarely practiced it while it fostered communicative gaps between them (Asemota 2015). The reasons behind this addressed to at least three significant motives; limited teaching experiences, non-teaching passion, and awareness of fully being a teacher. Length of teaching causes the different levels of teacher's performance. In addition, power plays a significant role in learning outcomes (Zam Zam Al Arif 2019)—one who puts passion into work affects better performance than those who do not. For example, the well-prepared teacher performs more related to teaching and easily managed activities. However, an unknowledgeable teacher utilizing instructional discourages learners' creative thinking (Tanggoro 2015) to active learning. Such an issue often drives a dummy routine. Colorful understanding has been overlooked (Bolla 2014), affecting learners not to be in the actual class. A workbook was the most first-used practice instead of self-media design.

One of the reasons for the emergence of this problem is the shortage of media use and teaching content amidst the students' activities. Media design as a tactical step in the teaching process must be practical and exciting. The idea is that teaching for specific purposes calls specific course design (Mavor and Trayner 2001). EFL teachers hope to integrate content into a closely authentic environment (Banegas, Corrales, and Poole 2020), not with a textbook that is not convenient, mainly ESOL textbooks (Chan and Cheuk 2020). It is widely believed that media reduce problems in response to classroom challenges. The selection of teaching media as a teaching tool, including preparing a specified text, planning activities, and setting instructional goals (Schutz, Danielson, and Cohen 2019), optimizes learners' concentration to learning involvement. There are at least three media benefits; First, teaching aids simplify explaining abstract things. Second, teaching aids help ease the ambiguity and complexity of teaching materials. Third, teaching media can cover the lack of teachers in communicating the material taught.

This paper intended to design and test local content-based learning media in English for the tourism class. The local content selected was the media of local public figures to write an autobiography for emerging genres (Brisk, Tian, and Ballard 2021). Thought idea is a participatory effort to contribute better to teaching quality since recognized materials are more understandable and easily implemented. The media in aid of teaching is believed to influence classroom practice in which output-oriented learning impacts both teacher's performance and learners as users. Furthermore, this research formulates the research question on "how local content is effectively practiced for tourism class and its impact on learners' writing descriptive?"

\section{Method}

The paper employs participatory action research with a learning cycle model. Such a teaching model tests the effectiveness of using local content-based teaching media in English for tourism classes. A total of participants were 15 taken from the first three-month course and tried in restricted class size. The learning cycle was taken 
within four meetings with 90 minutes of average teaching time. The last reflection step was evaluation at the end of the meeting to measure both vocabularies and write a local autobiography.

The learning cycle included four learning procedures; planning, acting, observing, and reflecting. The planning process covered the preparation of learning tools such as providing media of local content, teaching scenarios or lesson planning (comprising learning steps, detailed activities, and evaluation), and tests as a measuring tool for learning outcomes. The teaching and learning process was carried out at the acting stage using the local public figure designed with various activities agreed upon by the teaching team. The learning activity model adopted a genre approach with three phases; deconstruction, joint construction, and independent construction (De Oliveira and Lan 2014). In the third stage, we recorded the students' participation through participative observation and their involvement for evaluation.

The last stage is reflection evaluating the results of students' achievement tests. We then checked, recorded, and conducted an in-depth evaluation of three categories; media quality, learning participation records, and test results for the progress. In the effort of ideally improving media, content and look are becoming our concerns. Students are declared complete classically with $70 \%$ above the passing grade in the first cycle. In that case, the media of local content is declared suitable for use on broader class sizes in other schools with a similar level.

\section{Results and Discussions}

The local content teaching media in the tourism class focuses on the study of writing descriptive public figures. At the start of the investigation, diagnostic tests were administered to 15 participants, including two types of tests; Vocabulary test and test of writing biographies of local figures. Helping the test was aimed at finding out in detail the basic abilities of tourism class students as a measure of success used to compare the local media content being taught. The vocabulary diagnostic test contained only thirty words and adjective phrases describing the physical characteristics of figures in the two test models; matching words and gap-fill. Of the 15 participants who took the test, most were in the fragile category with a mastery criterion of less than one-half of the accumulated test (under fifty percent answered correctly). There were only two students in the good category with scores in the $80-100 \%$ word range, five students in the weak category. The rest was one student with sufficient category.

Tabel 1. Word diagnostic test

\begin{tabular}{lccc}
\hline \multicolumn{1}{c}{ Category } & Score & Number & Percentage \\
\hline Good & $80-100$ & 2 & $13 \%$ \\
Sufficient & $60-79$ & 1 & $7 \%$ \\
Poor & $50-59$ & 5 & $33 \%$ \\
Very poor & $<50$ & 7 & $47 \%$ \\
Classical passing grade $20 \%$, (standard : 70\% pass) & & \\
\hline Note: & & \\
Test items: 30 (words and phrases) & & \\
N: 15 & & \\
Classical passing grade: $70 \%$ & & \\
Score (number of correct items/number of items x 100) & & \\
\hline
\end{tabular}

The second test as part of the diagnostic is a written test. We provided participants with a blank sheet of a paper formatted. They were asked to write a description of the local figures provided with 60 minutes. This test concluded that the participants faced severe problems in writing. The first challenge was the inability of participants to elaborate their more extended ideas in a coherent paragraph organization. The majority of the script only focused on the physical description of the characters, although some participants narrated their educational and family backgrounds. The length of the articles collected only ranged from 60-100 words, from a minimum of $150-250$ words were required. We conclude that this limitation is due to the lack of solid vocabulary in the diagnostic record or perhaps because writing assistance has not been taught.

The second problem was grammar. The placement of "to be" often dominated the sentence even though its use was sometimes unnecessary. It can be understood from the participants' writings that the "to be" application was usually placed in sentence construction that already had a complete verb. Another situation was the absence of the "to be." That should exist due to the missing verb in the sentence being written. For 
example, participants wrote, "He is teach in University," "He from Sumbawa." The second problem of grammar found was pronouns. The use of overlapping pronouns was our concern. They still had difficulty distinguishing the use of third-person singular, masculine and feminine pronouns such as in the sentence "He is a politician, he name is Fahri Hamzah." "He is famous because he is smart," etc.

\section{Teaching Local Content}

The first cycle was a period of three teaching meetings using local content media titled local public figures. The choice of this topic was considered necessary, considering that the proximity of the content and which means to mediate would be profound (Vold and Brkan 2020) to the participants' understanding help activate learners more. Teaching genres in the context of the local text is essential. According to (Melissourgou and Frantzi 2017) that the idea of applying genres connect students to their life. They believe more than genre-knowledge in language writing; contents reflect cultures and communities. We aggre with the notion of what has been explained by Melissourgous and Frantzi (2017) that related content of teaching must potraits what students understand at most.

Furthermore, we implemented the teaching cycle in four detailed procedural steps; planning, acting, observing, and reflecting. At the planning stage, we formulated a learning plan by identifying problems from previous diagnostic tests, and selecting teaching materials, designing local media content, making systematic delivery of materials, developing strategies and learning activities, and constructing evaluation instruments at the end of teaching. The evaluation preparation at the reflection stage served to measure the success of the planned process.

The local content media design process focused on content and display design. The form of media should be attractive (Sholihin et al. 2020) because it can affect learning outcomes. Various media in teaching are meaningful; in the sense that they help improve better teaching. Although online learning is becoming popular, it is believed to be innovative (Syakur, Fanani, and Ahmadi 2020), even though some reject it. The criteria for media design were adjusted to the content and indicators that were determined (text organization $\&$ grammar). The form of local media content developed was graphic images with the size of A4 polio paper that represented local figures. The local figures in question were regional figures from various professions who already had names and were widely known nationally. The primary material used was stiff quarto paper measuring $210 \times 297 \mathrm{~mm}$. As a constituent of the media, the media components were coated with colored manila paper glued together with glue as a backcourt to strengthen the media. The Corel Draw application was also used to beautify the appearance of the media combined with modified colors and features around the media to attract the interest of learning participants.

After the validation process we carried out, the media created would then be realized for testing. The evaluation and revision stages were carried out to improve the appearance and content of the teaching media if the test results do not meet the eligibility standards and student learning progress in the classroom.

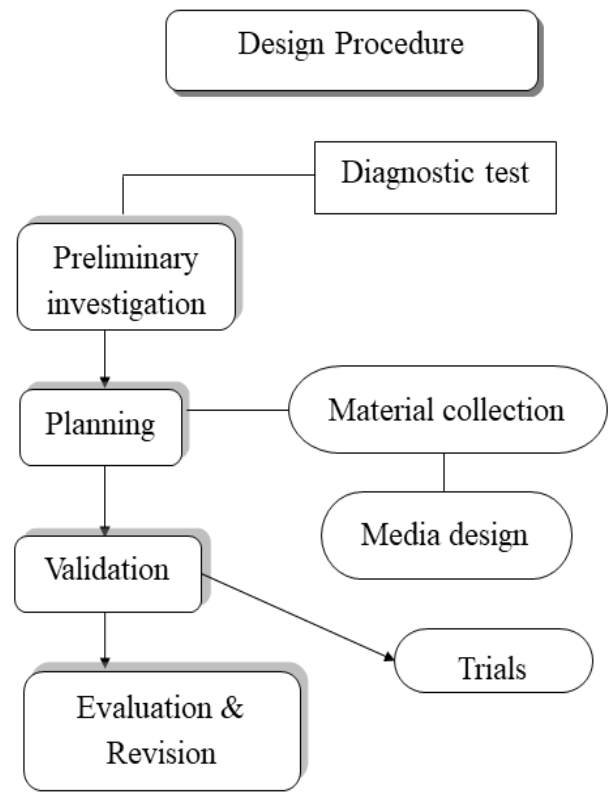

Figure 1. Design procedure of local content media 
Initial investigations on diagnostic tests have noted several vital things related to what material content to teach. The media trial at the first meeting was carried out on 15 test subjects after the media had been designed and agreed to be valid. The topics taught are "Local Public figures" with two indicators of successful learning achievement; 1) ability to recognize and identify the structure of text including; identification, classification, description, 2) linguistic features that focus on discussing the simple present and pronouns.

On the first day, we taught a modified descriptive text. We believe that integrated literature evokes emotion and language development and students' experiences (Pourbahram, R. \& Hajizadeh 2018). The text taught drives better students if it is close to their prior knowledge. The text discusses the short biography of Joko Widodo, the President of Indonesia. To start the class, we wrote the word idol on the board. We then provoked a question with "Is there anyone in this class who idolizes someone?", "Who is your idol?" "Why do you like it?" After several responses, the teacher then showed some photos of the characters that had been prepared (singer, actor, president, politician, and comedian). Because we were targeting the study on the descriptive text structure, we started the question by showing one of the president's photos. We then directed participants to questions about character recognition, character identification, and description.

In the main teaching session, learning activities adopted a pair-work pattern. Participants were instructed to sit in two. The study materials distributed were lists of adjectives and texts to read and discuss. We modeled how the words were produced and then asked students to imitate what was said. For five minutes, we then checked students' understanding of the vocabulary shared. The comprehension test mentioned several vocabulary words to find their equivalent in the target language. To strengthen students' knowledge of the vocabulary and the text read, we provided exercises in vocabulary containing most adjective words and phrases taken from the text. For 30 minutes, we directed course-takers to discuss the content of the text and work on vocabulary assignments.

The next activity is task checking. We simultaneously checked assignments for correction if some words or phrases were incorrectly paired. In the remaining time, we invited participants to discuss the content of the text and then focused on explaining the three main elements of the descriptive text; identification, classification, and description. We discussed in detail which sections belong to these three sections. In the closing activity, we asked participants to conclude what they had learned, and as additional material, they were asked to read biographies of characters at home.

Ice-breaking on the second day focused on talking about local figures. We showed one very familiar character, "Tuan Guru Bajang, TGKH. Muhammad Zainul Majdi." At the beginning of the lesson, we built good rapport (Anon 2015) to facilitate the learning process. Participants enthusiastically said a few sentences about Tuan Guru Bajang. What's interesting is that they gave their views on Tuan Guru Bajang. Giving topics that they understand will maximize involvement in learning. We directed participants to some adjectives and phrases attached to physical and career characteristics at the description time. We often helped participants with vocabulary or phrases they were not familiar with. For 40 minutes, students were distributed worksheets to choose one of the four figures provided. In the last 30-minute session, the teacher chose an example of a student's writing to be discussed. The thing that became the focus of correction was the use of "to be" and "pronoun." In the closing activity, homework was assigned to each student to write a description of local figures they knew to be collected at the next meeting. Successful teaching of writing public figures is not only because of the exciting content, but it lies on teachers' belief (Kelly, L.B 2017).

On the third day, which was the last day, we maximized our first time to check students' work. Of the 15 participants, almost 70 percent have understood the use of "to be" and "pronoun" in their writing. Next, we instructed the students to write about idolized local figures to complete their writing assignments and train students' understanding of the learning content. We did mingling activities while occasionally checking students' writing and helping them if there were some mistakes.

We provided the test for evaluation to 15 experimental subjects with two types of questions; vocabulary and writing tests. Eleven students were declared complete with a class completeness percentage of $73 \%$, and three students were in the poor category $(57,57,53$ with a rate of $20 \%$ and one student was declared failed because of being absent from the test day. The test results in the first trial experienced an increase. This information is based on the improvement in grades of the students who passed the test. The previous diagnostic test obtained an average score of 51 where the number of students who were declared complete in class was only $20 \%$, one-fifth of the total number of students. Even though the highest score in the previous test was as high as 87, students' minimum score was as deficient as 27. The percentage of students' completeness on the first test in the first cycle shows significant progress. This second test has increased scores by $53 \%$ in class completeness with an average score of 76 with the highest score of 97. 
Table 2. Overall test

\begin{tabular}{lcc|}
\hline \multicolumn{3}{c|}{ Word Diagnostics } \\
\hline \multicolumn{1}{c}{ Category } & Number & Classical passing grade \\
Good & 2 & \\
Sufficient & 1 & \\
Poor & 5 & \\
Very poor & 7 & \\
Max & 87 & \\
Min & 27 & \\
Average & 51 & Classical passing grade \\
\multicolumn{1}{c}{ Category } & Number & \\
Good & 11 & \\
Sufficient & 2 & \\
Poor & - & \\
Very poor & - & \\
Max & 97 & \\
Min & 57 & \\
Average & 76 & \\
Note: & & \\
Test items: 30 (words and phrases) & & \\
N: 15 & & \\
Classical passing grade: $70 \%$ & & \\
Score (number of correct items/number of items x 100) & \\
\hline
\end{tabular}

The second test, held on May 6, 2021, concluded that the students' ability to write descriptions of local figures conformed to the writing standards according to the indicators planned. More than 12 students stated to have a good understanding of when to use and not to use "to be." We found that the course-takers comprehension of descriptive sentence narration was written with the correct use of "pronouns" even though a few were misused.

\section{Conclusions}

The selection of local content-based teaching materials in the tourism class plays a central role in improving the skills of writing descriptive text. The design of material content containing photos and biographies of prominent local figures is perfect for teaching communicative writing. Cognitively, the presentation of local content material has succeeded in bringing about an impact on the learning scores and effectively growing responsive attention. The test at the reflection stage showed a significant increase in vocabulary mastery from the average score, 51 previously on the diagnostic test to 76 on the final examination. There were only 3 participants who met the passing grade (standard score, 70) with a percentage of twenty percent in the class. Still, this number increased sharply after using local public figures media with an accumulated increase of fiftythree percent completed in class.

On the other hand, local public figures effectively teach linguistic features such as the simple present tense ( to be and pronouns). Intensive guidance and individual correction during writing assignments became the determinants of participants' success. Other factors, namely preparing coherent learning activities (building rapport in pre-teaching, word exposure, accurate sample text, exercise) and the continuity of related teaching content from the first day to the third day, led to the strengthening of concepts remembered longer. Of the 14 students who have taken the test, almost all of the participants could use pronouns correctly even though there were one or two participants who were still not perfect in placing masculine or feminine pronouns. Due to the limitations and scope, this research can be helpful in reference classroom teaching media development using local content to be tested on a broader class scale. Selective teaching content familiar with participants' knowledge can be adopted to reduce dummy classes to learn productivity is alive and meaningful. Furthermore, identifying student problems needs to be done to prepare better future instructional desired. 


\section{References}

Akbari, Zahra. 2015. "Current Challenges in Teaching / Learning English for EFL Learners: The Case of Junior High School and High School." Procedia - Social and Behavioral Sciences 199:394-401. doi: 10.1016/j.sbspro.2015.07.524.

Al-Jarrah, Tamer Mohammad, Jarrah Mohammad Al-Jarrah, Rania Hassan Talafhah, and Noraien Mansor. 2019. "The Role of Social Media in Development of English Language Writing Skill at School Level." International Journal of Academic Research in Progressive Education and Development 8(1):87-99. doi: 10.6007/ijarped/v8-i1/5537.

Anon. 2015. "THE INTEGRATION OF RAPPORT IN ENGLISH LANGUAGE TEACHING Abdul Halim." 1(1):69-84.

Asemota, Henry Erhamwenmwonyi. 2015. "The Role of Media in English Language Development." International Journal of Humanities and Social Science Studies (IJHSSS) 2(3):311-16.

Banegas, Darío Luis, Kathleen Corrales, and Paige Poole. 2020. "Can Engaging L2 Teachers as Material Designers Contribute to Their Professional Development? Findings from Colombia." System 91:102265. doi: 10.1016/j.system.2020.102265.

Bolla, Mallikharjuna Rao. 2014. "Use of Media as an Instructional Tool in English Language Teaching (ELT) at Undergraduate Level." International Journal of English and Literature 5(6):141-43. doi: 10.5897/ijel2014.0580.

Brisk, María Estela, Zhongfeng Tian, and Ed Ballard. 2021. "Autobiography Writing Instruction: The Journey of a Teacher Participating in a Systemic Functional Linguistics Genre Pedagogy Professional Development." System 97:102429. doi: 10.1016/j.system.2020.102429.

Chan, Hang, and Hiu Ngai Jessica Cheuk. 2020. "Revisiting the Notion of ESL: A Corpus-Based Analysis of English Textbook Instructional Language." Ampersand 7(June):100066. doi: 10.1016/j.amper.2020.100066.

Elizabeth, Anna, and Du Plessis. 2018. "Barriers to e Ff Ective Management of Diversity in Classroom Contexts : The out-of- Fi Eld Teaching Phenomenon." (November 2017). doi: 10.1016/j.ijer.2018.11.002.

Garcia-Ponce, Edgar Emmanuell, and Caroline Tagg. 2020. "Role of EFL Teachers' Beliefs in Speaking Practice: The Case of a Mexican University." System 95:102376. doi: 10.1016/j.system.2020.102376.

Ho, Ya-yu Cloudia. 2020. "Sport \& Tourism Education Communicative Language Teaching and English as a Foreign Language Undergraduates' Communicative Competence in Tourism English." Journal of Hospitality, Leisure, Sport \& Tourism Education 27(1):100271. doi: 10.1016/j.jhlste.2020.100271.

Huang, Xianhan, John Chi-Kin Lee, and Xiaoping Yang. 2019. "What Really Counts? Investigating the Effects of Creative Role Identity and Self-Efficacy on Teachers' Attitudes towards the Implementation of Teaching for Creativity." Teaching and Teacher Education 84:57-65. doi: 10.1016/j.tate.2019.04.017.

Inharjanto, Anselmus, and Lisnani. 2021. "Elt Learning Media For Young Learners : Family-Themed Picture Stories." Indonesian EFL Journal (IEFLJ) 7(1):21-32.

Li, Guofang, Zhuo Sun, and Youngeun Jee. 2019. "AC." System. doi: 10.1016/j.system.2019.05.003.

Li, Li. 2019. "SC." doi: 10.1016/j.tsc.2019.03.001.

Manca, Stefania, and Maria Ranieri. 2016a. "Internet and Higher Education' Yes for Sharing, No for Teaching !': Social Media in Academic Practices." The Internet and Higher Education 29:63-74. doi: 10.1016/j.iheduc.2015.12.004.

Manca, Stefania, and Maria Ranieri. 2016b. "SC." Computers \& Education. doi: 10.1016/j.compedu.2016.01.012.

Mavor, Sally, and Beverly Trayner. 2001. "Aligning Genre and Practice with Learning in Higher Education: An Interdisciplinary Perspective for Course Design and Teaching." English for Specific Purposes 20(4):34566. doi: 10.1016/S0889-4906(01)00025-4.

Melissourgou, Maria N., and Katerina T. Frantzi. 2017. "Genre Identification Based on SFL Principles: The Representation of Text Types and Genres in English Language Teaching Material." Corpus Pragmatics 1(4):373-92. doi: 10.1007/s41701-017-0013-z.

Montiel, Ivan, Javier Delgado-Ceballos, Natalia Ortiz-de-Mandojana, and Raquel Antolin-Lopez. 2020. "New Ways of Teaching: Using Technology and Mobile Apps to Educate on Societal Grand Challenges." Journal of Business Ethics 161(2):243-51. doi: 10.1007/s10551-019-04184-x.

De Oliveira, Luciana C., and Shu Wen Lan. 2014. "Writing Science in an Upper Elementary Classroom: A Genre-Based Approach to Teaching English Language Learners." Journal of Second Language Writing 25(1):23-39. doi: 10.1016/j.jslw.2014.05.001.

Peralta, Angel, and Nicholas Caporusso. 2020. "The Impact of Social Media in Military Recruiting." Advances in Intelligent Systems and Computing 1215 AISC(August):415-20. doi: 10.1007/978-3-030-51549-2_55.

Pourbahram, R. \& Hajizadeh, M. 2018. "Language Teaching and Educational Research." Language Teaching 
and Educational Research 1(1):1-12.

Rankin, Jean, and Val Brown. 2015. NU SC. Elsevier B.V.

Rus, Dana, and Dana Rus. 2020. "ScienceDirect ScienceDirect ScienceDirect Creative Methodologies in Teaching English for Engineering Creative Methodologies in Students Teaching English for Engineering Students." Procedia Manufacturing 46:337-43. doi: 10.1016/j.promfg.2020.03.049.

Salinas, Alejandra, Chu Ly, Jeanne R. Paratore, Lisa M. O. Brien, and Laura Jim. 2016. "Engaging Preservice Teachers in Integrated Study and Use of Educational Media and Technology in Teaching Reading." Teaching and Teacher Education 59:247-60. doi: 10.1016/j.tate.2016.06.003.

Schutz, Kristine M., Katie A. Danielson, and Julie Cohen. 2019. "Approximations in English Language Arts: Scaffolding a Shared Teaching Practice." Teaching and Teacher Education 81:100-111. doi: 10.1016/j.tate.2019.01.004.

Sholihin, Mahfud, Ratna Candra, Nurhening Yuniarti, and Sariyatul Ilyana. 2020. "The International Journal of Management Education A New Way of Teaching Business Ethics : The Evaluation of Virtual RealityBased Learning Media ț." The International Journal of Management Education 18(3):100428. doi: 10.1016/j.ijme.2020.100428.

Syakur, Abd., Zainal Fanani, and Rulam Ahmadi. 2020. "The Effectiveness of Reading English Learning Process Based on Blended Learning through 'Absyak' Website Media in Higher Education." Budapest International Research and Critics in Linguistics and Education (BirLE) Journal 3(2):763-72. doi: 10.33258/birle.v3i2.927.

Tanggoro, Urip. 2015. "The Use of Instructional Media to Improve Students' Motivation in Learning English." Dialektika 3(1):100-107.

Tsai, Chih-yung, Ya-han Chang, and Chia-lun Lo. 2017. "SC." Thinking Skills and Creativity. doi: 10.1016/j.tsc.2017.11.003.

Vieluf, Svenja, and G. Kerstin. 2019. "Making Intercultural Learning in EFL Lessons Interesting e The Role of Teaching Processes and Individual Learning Prerequisites and Their Interactions." 79. doi: 10.1016/j.tate.2018.11.019.

Vold, Eva Thue, and Altijana Brkan. 2020. "Classroom Discourse in Lower Secondary French-as-a-ForeignLanguage Classes in Norway: Amounts and Contexts of Fi Rst and Target Language Use." System 93:102309. doi: 10.1016/j.system.2020.102309.

Wang, Lijuan, and Dimitra Kokotsaki. 2018. "Primary School Teachers' Conceptions of Creativity in Teaching English as a Foreign Language (EFL) in China." Thinking Skills and Creativity. doi: 10.1016/j.tsc.2018.06.002.

Wirawan, Fajar. 2020. "A Study on The Teaching Media Used by The English Teacher at SMP Muhammadiyah 2 Malang." Jurnal Ilmiah Profesi Pendidikan 5(2):89-95. doi: 10.29303/jipp.v5i2.115.

Zam Zam Al Arif, Tubagus. 2019. "The Use of Social Media for English Language Learning: An Exploratory Study of Efl University Students." Metathesis: Journal of English Language, Literature, and Teaching 3(2):22433. doi: 10.31002/metathesis.v3i2.1921.

Zeybeck, G. 2018." Turkish Pre-service EFL Teachers Views in Integrating Various Literary Genres in Teaching English. Language Teaching and Educational Research. 2018-1,25-41

Akbari, Zahra. 2015. "Current Challenges in Teaching / Learning English for EFL Learners: The Case of Junior High School and High School." Procedia - Social and Behavioral Sciences 199:394-401. doi: 10.1016/j.sbspro.2015.07.524.

Al-Jarrah, Tamer Mohammad, Jarrah Mohammad Al-Jarrah, Rania Hassan Talafhah, and Noraien Mansor. 2019. "The Role of Social Media in Development of English Language Writing Skill at School Level." International Journal of Academic Research in Progressive Education and Development 8(1):87-99. doi: 10.6007/ijarped/v8-i1/5537.

Anon. 2015. "THE INTEGRATION OF RAPPORT IN ENGLISH LANGUAGE TEACHING Abdul Halim." 1(1):69-84.

Asemota, Henry Erhamwenmwonyi. 2015. "The Role of Media in English Language Development." International Journal of Humanities and Social Science Studies (IJHSSS) 2(3):311-16.

Banegas, Darío Luis, Kathleen Corrales, and Paige Poole. 2020. "Can Engaging L2 Teachers as Material Designers Contribute to Their Professional Development? Findings from Colombia." System 91:102265. doi: 10.1016/j.system.2020.102265.

Bolla, Mallikharjuna Rao. 2014. "Use of Media as an Instructional Tool in English Language Teaching (ELT) at Undergraduate Level." International Journal of English and Literature 5(6):141-43. doi: 10.5897/ijel2014.0580.

Brisk, María Estela, Zhongfeng Tian, and Ed Ballard. 2021. "Autobiography Writing Instruction: The Journey of a Teacher Participating in a Systemic Functional Linguistics Genre Pedagogy Professional Development." System 97:102429. doi: 10.1016/j.system.2020.102429. 
Chan, Hang, and Hiu Ngai Jessica Cheuk. 2020. "Revisiting the Notion of ESL: A Corpus-Based Analysis of English Textbook Instructional Language." Ampersand 7(June):100066. doi: 10.1016/j.amper.2020.100066.

Elizabeth, Anna, and Du Plessis. 2018. "Barriers to e Ff Ective Management of Diversity in Classroom Contexts : The out-of- Fi Eld Teaching Phenomenon." (November 2017). doi: 10.1016/j.ijer.2018.11.002.

Garcia-Ponce, Edgar Emmanuell, and Caroline Tagg. 2020. "Role of EFL Teachers' Beliefs in Speaking Practice: The Case of a Mexican University." System 95:102376. doi: 10.1016/j.system.2020.102376.

Ho, Ya-yu Cloudia. 2020. "Sport \& Tourism Education Communicative Language Teaching and English as a Foreign Language Undergraduates' Communicative Competence in Tourism English." Journal of Hospitality, Leisure, Sport \& Tourism Education 27(1):100271. doi: 10.1016/j.jhlste.2020.100271.

Huang, Xianhan, John Chi-Kin Lee, and Xiaoping Yang. 2019. "What Really Counts? Investigating the Effects of Creative Role Identity and Self-Efficacy on Teachers' Attitudes towards the Implementation of Teaching for Creativity." Teaching and Teacher Education 84:57-65. doi: 10.1016/j.tate.2019.04.017.

Inharjanto, Anselmus, and Lisnani. 2021. "Elt Learning Media For Young Learners : Family-Themed Picture Stories." Indonesian EFL Journal (IEFLJ) 7(1):21-32.

Li, Guofang, Zhuo Sun, and Youngeun Jee. 2019. "AC." System. doi: 10.1016/j.system.2019.05.003.

Li, Li. 2019. "SC." doi: 10.1016/j.tsc.2019.03.001.

Manca, Stefania, and Maria Ranieri. 2016a. "Internet and Higher Education' Yes for Sharing , No for Teaching!': Social Media in Academic Practices." The Internet and Higher Education 29:63-74. doi: 10.1016/j.iheduc.2015.12.004.

Manca, Stefania, and Maria Ranieri. 2016b. "SC." Computers \& Education. doi: 10.1016/j.compedu.2016.01.012.

Mavor, Sally, and Beverly Trayner. 2001. "Aligning Genre and Practice with Learning in Higher Education: An Interdisciplinary Perspective for Course Design and Teaching." English for Specific Purposes 20(4):34566. doi: 10.1016/S0889-4906(01)00025-4.

Melissourgou, Maria N., and Katerina T. Frantzi. 2017. "Genre Identification Based on SFL Principles: The Representation of Text Types and Genres in English Language Teaching Material." Corpus Pragmatics 1(4):373-92. doi: 10.1007/s41701-017-0013-z.

Montiel, Ivan, Javier Delgado-Ceballos, Natalia Ortiz-de-Mandojana, and Raquel Antolin-Lopez. 2020. "New Ways of Teaching: Using Technology and Mobile Apps to Educate on Societal Grand Challenges." Journal of Business Ethics 161(2):243-51. doi: 10.1007/s10551-019-04184-x.

De Oliveira, Luciana C., and Shu Wen Lan. 2014. "Writing Science in an Upper Elementary Classroom: A Genre-Based Approach to Teaching English Language Learners." Journal of Second Language Writing 25(1):23-39. doi: 10.1016/j.jslw.2014.05.001.

Peralta, Angel, and Nicholas Caporusso. 2020. "The Impact of Social Media in Military Recruiting." Advances in Intelligent Systems and Computing 1215 AISC(August):415-20. doi: 10.1007/978-3-030-51549-2_55.

Pourbahram, R. \& Hajizadeh, M. 2018. "Language Teaching and Educational Research." Language Teaching and Educational Research 1(1):1-12.

Rankin, Jean, and Val Brown. 2015. NU SC. Elsevier B.V.

Rus, Dana, and Dana Rus. 2020. "ScienceDirect ScienceDirect ScienceDirect Creative Methodologies in Teaching English for Engineering Creative Methodologies in Students Teaching English for Engineering Students." Procedia Manufacturing 46:337-43. doi: 10.1016/j.promfg.2020.03.049.

Salinas, Alejandra, Chu Ly, Jeanne R. Paratore, Lisa M. O. Brien, and Laura Jim. 2016. "Engaging Preservice Teachers in Integrated Study and Use of Educational Media and Technology in Teaching Reading." Teaching and Teacher Education 59:247-60. doi: 10.1016/j.tate.2016.06.003.

Schutz, Kristine M., Katie A. Danielson, and Julie Cohen. 2019. "Approximations in English Language Arts: Scaffolding a Shared Teaching Practice." Teaching and Teacher Education 81:100-111. doi: 10.1016/j.tate.2019.01.004.

Sholihin, Mahfud, Ratna Candra, Nurhening Yuniarti, and Sariyatul Ilyana. 2020. "The International Journal of Management Education A New Way of Teaching Business Ethics : The Evaluation of Virtual Reality-

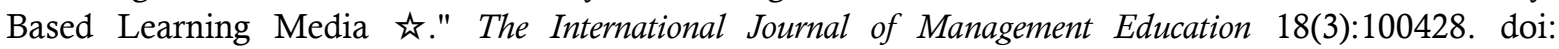
10.1016/j.ijme.2020.100428.

Syakur, Abd., Zainal Fanani, and Rulam Ahmadi. 2020. "The Effectiveness of Reading English Learning Process Based on Blended Learning through 'Absyak' Website Media in Higher Education." Budapest International Research and Critics in Linguistics and Education (BirLE) Journal 3(2):763-72. doi: 10.33258/birle.v3i2.927.

Tanggoro, Urip. 2015. "The Use of Instructional Media to Improve Students' Motivation in Learning English." Dialektika 3(1):100-107.

Tsai, Chih-yung, Ya-han Chang, and Chia-lun Lo. 2017. "SC." Thinking Skills and Creativity. doi: 
10.1016/j.tsc.2017.11.003.

Vieluf, Svenja, and G. Kerstin. 2019. "Making Intercultural Learning in EFL Lessons Interesting e The Role of Teaching Processes and Individual Learning Prerequisites and Their Interactions." 79. doi: 10.1016/j.tate.2018.11.019.

Vold, Eva Thue, and Altijana Brkan. 2020. "Classroom Discourse in Lower Secondary French-as-a-ForeignLanguage Classes in Norway: Amounts and Contexts of Fi Rst and Target Language Use." System 93:102309. doi: 10.1016/j.system.2020.102309.

Wang, Lijuan, and Dimitra Kokotsaki. 2018. "Primary School Teachers' Conceptions of Creativity in Teaching English as a Foreign Language (EFL) in China." Thinking Skills and Creativity. doi: 10.1016/j.tsc.2018.06.002.

Wirawan, Fajar. 2020. "A Study on The Teaching Media Used by The English Teacher at SMP Muhammadiyah 2 Malang." Jurnal Ilmiah Profesi Pendidikan 5(2):89-95. doi: 10.29303/jipp.v5i2.115.

Zam Zam Al Arif, Tubagus. 2019. "The Use of Social Media for English Language Learning: An Exploratory Study of Efl University Students." Metathesis: Journal of English Language, Literature, and Teaching 3(2):22433. doi: 10.31002/metathesis.v3i2.1921. 